\title{
Fertility preservation healthcare circuit and networks in cancer patients worldwide: what are the issues?
}

\author{
Kathleen Melan ${ }^{1}$, Frederic Amant ${ }^{2}$, Jacqueline Veronique-Baudin ${ }^{3}$, Clarisse Joachim ${ }^{3 *}$ and Eustase Janky ${ }^{1,4}$
}

\begin{abstract}
Background: Fertility preservation (FP) is a major determinant of quality of life after cancer remission for women who may not have achieved their ideal family size. This article describes the FP services and strategy currently available, highlighting issues of oncofertility worldwide.

Main body of the abstract: For these patients in complex situations, health networks are essential to improve coordination of care, and the strengthening of this coordination is a major challenge to improve the performance of the health system. Two international networks have been created in order to foster scientific exchange between countries and to standardize the oncofertility healthcare circuit. However, the paucity of referral nationwide networks lead to a structural gap in health care policies.

Short conclusion: Management strategies of oncofertility in the world are still fragile and uneven. To structure the oncofertility sector, a multidisciplinary project allowing teams to collaborate is of utmost importance particularly in low and middle-income countries.
\end{abstract}

Keywords: Oncofertility, Cancer therapies, Fertility preservation, Quality of life, Healthcare management

\section{Background}

Oncofertility is a new transversal concept that describes an integrated network focused on medical methods to spare or restore reproductive function in patients diagnosed with cancer. The term was coined in 2006 in the USA, although the history of oncofertility dates back to 1971, with the signature of the National Cancer Act. Oncofertility connects disciplines such as oncology, reproductive medicine, sexology, pediatrics and bioethics. Gone are the days when the only goal was to cure cancer, and oncofertility has taken over as the medical field concerned with minimizing the negative effects of cancer treatment on the reproductive system and fertility, and aiming to assist individuals with reproductive impairments resulting from cancer therapy.

The substantial growth of the field of oncofertility is the result of increased cancer incidence and especially increases in post-cancer survival. In 2020, more than 7.9

\footnotetext{
* Correspondence: clarisse.joachim@chu-martinique.fr

${ }^{3}$ Oncology Haematology Urology Pathology Department, UF 1441 Cancer Research and Registry, University Hospital of Martinique, 127 Route de Redoute, Les jardins de la Mouïna, 97200 Fort-de-France, Martinique Full list of author information is available at the end of the article
}

million women will be diagnosed with cancer worldwide: around 3.7 million in Asia; 1.7 million in Europe; 1.5 million in America; 604,000 in Africa and 50,000 in the Caribbean [1]. Among female cancer survivors, 1 in 250 are of reproductive age [2]. Current therapeutic advances had led to growing numbers of young women who survive their cancer. It is considered that one young adult aged 20 to 30 years out of 1000 has survived a cancer in childhood [3]. In Europe, children diagnosed with cancer currently have a 5 -year-survival rate of $79.1 \%$ [4]. In the USA, about $10 \%$ of all female cancer survivors are younger than 45 years of age [5] and this rate is around $18.6 \%$ in the French West-Indies (FWI, Martinique). Every year, more than 15,000 reproductive-age women in France face a cancer diagnosis.

Both cancer and oncologic treatments are known to induce sexual dysfunction, gonadotoxicity and multiple mechanisms of impaired reproductive function, though the effects may be unpredictable [6-9]. A study conducted in South India by Rajendranath and al [10] on the long-term effects of cancer treatment in childhood cancer survivors found that $24.5 \%$ of them were 
diagnosed with impaired fertility; it was the first longterm effect found. The most constant determinants of fertility disorders in cancer survivors are chemotherapy, radiotherapy or surgery involving the reproductive organs. The available literature quantifying infertility risks has reported the highest risk rates $(>80 \%)$ associated with chemotherapy with alkylating agents.

Fertility preservation (FP) is a major determinant of quality of life after cancer remission for women who may not have completed their family or achieved their ideal family size [11].

It is essential to inform cancer patients about new techniques for fertility preservation and to integrate them into systematic long-term follow-up. Young women will have the opportunity to preserve reproductive functions without significant impact on their survival, as a result of this recently defined concept. Advances in oncofertility are the only hope to ensure future fertility of cancer patients worldwide.

Despite advances in technology and knowledge in the field of oncofertility, there is a major gap in the structure of fertility preservation management strategies in the world and in developed countries. This induces a lack of knowledge about fertility management options or more marked inequalities in access to care at referral centers among young women and girls diagnosed with cancer. In order to provide the hope of future fertility and to reduce disparities in access to care among all young female cancer survivors, it is currently important to study how fertility preservation networks are structured for cancer patients. This work aims to outline the landscape of organizational models and the chain of coordination of fertility preservation worldwide for female cancer patients. A literature review was conducted in 2016 by searching the electronic Medline and EMBASE databases for original and review articles concerning "fertility preservation", "oncofertility network" and "fertility after cancer" published up to 1st September 2016.

\section{Main text}

Fertility preservation healthcare circuit for young women: current strategy

Figures 1 and 2 show the fertility preservation healthcare circuit for female cancer patients commonly used worldwide. Unlike pubertal boys and men for whom sperm banking is an easy option, pubertal girls and young women face more difficulties when they hope to preserve their reproductive health. The female germ cell (only available in limited numbers) needs to be retrieved surgically mainly after hormonal stimulation, and will be at various levels of maturity depending on the length of the menstrual cycle. Currently, oocytes and embryo banking are standard of care for preserving fertility for reproductive-age cancer patients. The age, cancer site, timing and regimen of cancer treatment determine the

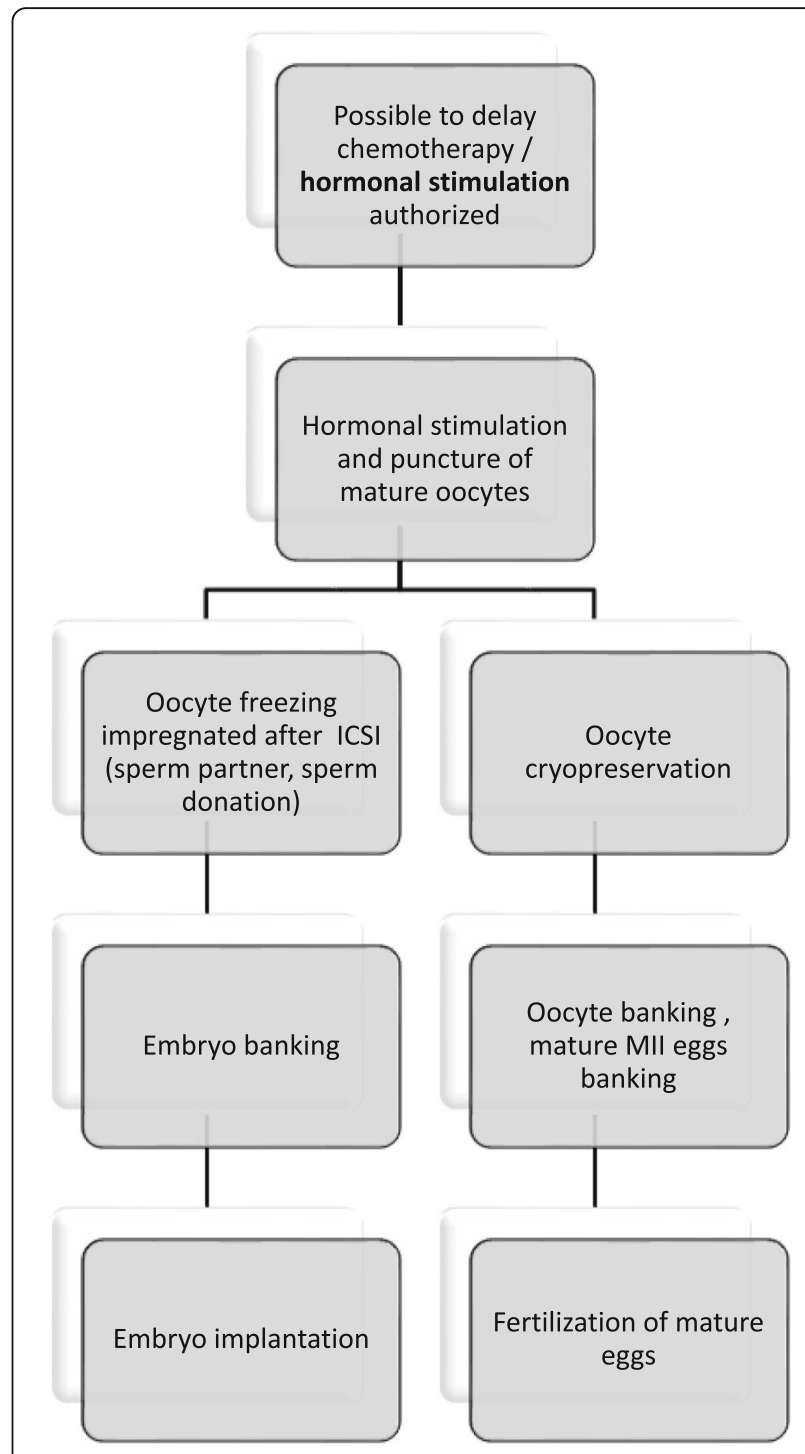

Fig. 1 Current therapeutic strategy for female oncofertility when it is possible to delay oncotherapy. ICSI: Intracytoplasmic sperm injection; MII = Metaphase II; IVM: In Vitro Maturation

optimal FP option. Excepting toxicity of treatments, the success of FP depends on the quality of the initial state of reproductive health of women before treatment. Little is known about the risk factors of various populations that should be taken into account.

Table 1 presents experimental levels, advantages, disadvantages and contraindications for FP options. While embryo cryopreservation is the first and most widely used option in the world, ovarian tissue banking is not universally available. Currently, there are relatively few medical centers with international experience in performing ovarian tissue banking: about 100 worldwide and including 23 in France [12]. An overview of Canadian practices [13] reported activities in terms of in vitro fertilization (IVF) across the country. They reported that 


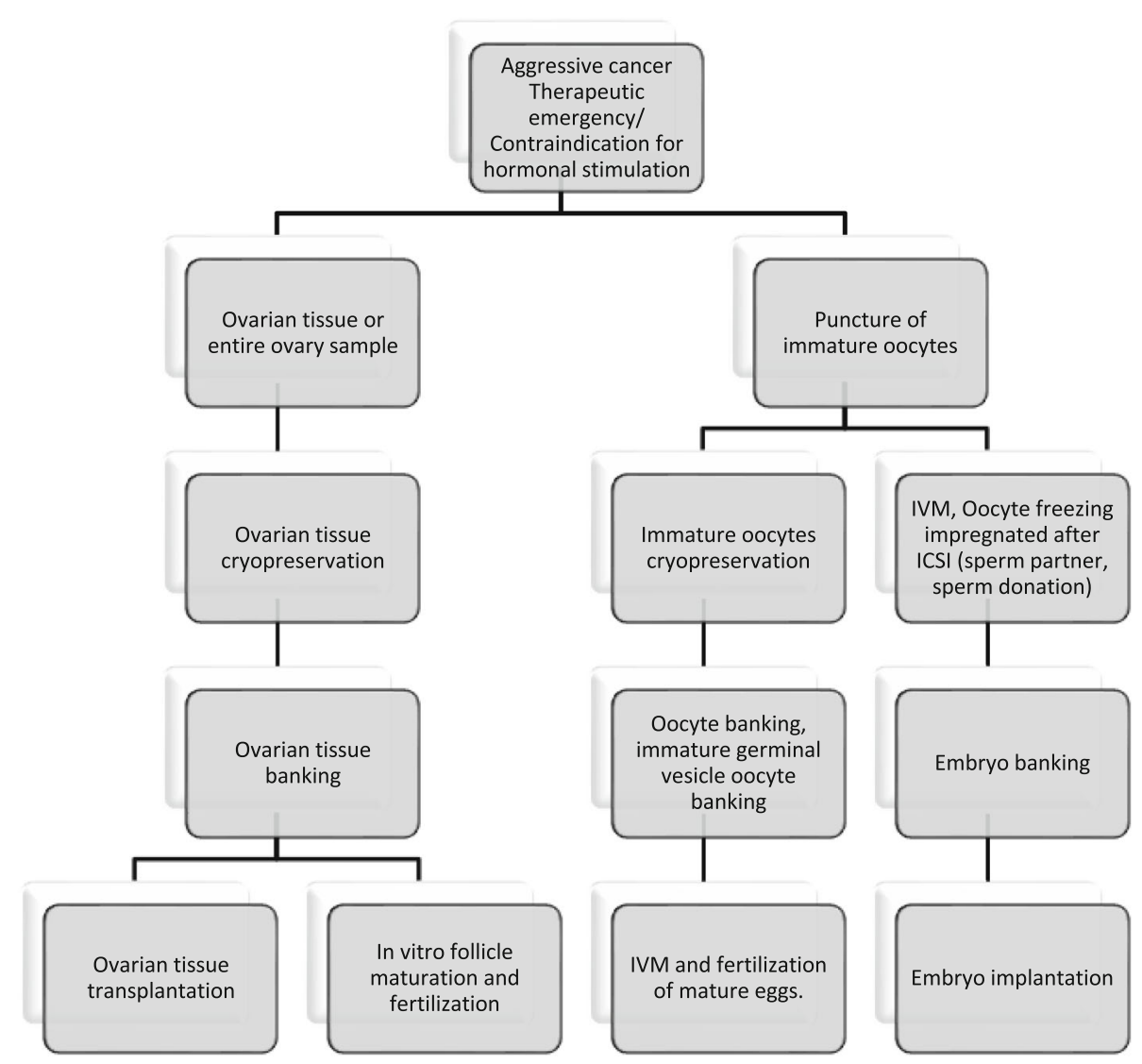

Fig. 2 Current therapeutic strategy for female oncofertility when it is NOT possible to delay oncotherapy. ICSI: Intracytoplasmic sperm injection; MII = Metaphase II; IVM: In Vitro Maturation

$100.0 \%$ of IVF centres provide embryo cryopreservation, $82.4 \%$ provide oocyte freezing, $29.4 \%$ provide in vitro maturation services, and only $17.6 \%$ provide ovarian tissue preservation. In the U.S.A., the recourse to gestational carriers is an option for women who have undergone hysterectomy or severe damage to the uterus caused by oncology therapies.

Table 2 presents outcomes of FP options in cancer patients around the world. The total number of live births from the fertilization of mature cryopreserved oocytes exceeded 1000 in 2010 [5]. InVitro Maturation (IVM) was performed worldwide for thousands of conceptions leading to healthy babies. The success rate for ovarian tissue transplantation is still low [14, 15]. Rodriguez-Wallberg et al. [16] showed promising results in terms of recovery of fertility in Nordic countries that have performed ovarian tissue transplantation procedures.

Currently, emerging technology is being developed: ovarian follicle culture in vitro, ovarian follicle transplantation, oogonial stem cells and in vitro activation of ovarian follicles. New FP options will continue to be developed.

\section{Organizational support of FP in cancer patients worldwide}

For these patients in complex situations, health networks are essential to improve coordination of care, and the strengthening of this coordination is a major challenge to improve the performance of the health system. Functional support is required to mobilize all the necessary resources and guarantee an efficient healthcare circuit.

Two major international networks have been created in order to foster scientific exchange between countries and to standardize the FP healthcare circuit for cancer patients. In 2015 the International Network on Cancer, Infertility and Pregnancy (INCIP) incorporated the "Cancer in pregnancy" registry founded in 2005. The INCIP established an international registry on cancer during pregnancy and FP during cancer treatment and promotes research aiming to increase knowledge among healthcare workers and the public. The data collected include oncological, gynecological and obstetric data. All cancer types and treatment modalities are included. This international network seeks to work in close collaboration with existing networks notably the European Society of Gynaecological Oncology (ESGO) Fertility Preservation. The FertiPROTEKT network, 
Table 1 Experimental level, advantages, disadvantages and contraindications of FP options used in oncofertility around the world

\begin{tabular}{|c|c|c|c|c|}
\hline FP option & Experimental level & Advantages & Disadvantages & Contraindication to FP technique \\
\hline $\begin{array}{l}\text { Embryo banking after puncture } \\
\text { of mature oocytes }\end{array}$ & Standard method & Mature technology & $\begin{array}{l}\text { Delay cancer treatment } \\
\text { by } 2-3 \text { weeks } \\
\text { Ethical and legal requirements } \\
\text { Need for a partner with whom } \\
\text { they wish to have a child }\end{array}$ & $\begin{array}{l}\text { Presence of a } \mathrm{Cl} \text { to } \\
\text { hormonal stimulation* }\end{array}$ \\
\hline $\begin{array}{l}\text { Embryo banking after puncture } \\
\text { of immature oocytes }\end{array}$ & Experimental methods & $\begin{array}{l}\text { Allows immediate } \\
\text { cancer treatment }\end{array}$ & $\begin{array}{l}\text { Ethical and legal requirements } \\
\text { Need for a partner with whom } \\
\text { they wish to have a child }\end{array}$ & \\
\hline Mature oocyte cryopreservation & $\begin{array}{l}\text { Experimental method } \\
\text { Alternative to embryo } \\
\text { cryopreservation for women } \\
\text { who do not have a partner } \\
\text { or do not want to use } \\
\text { donated sperm }\end{array}$ & $\begin{array}{l}\text { Legal property of } \\
\text { the woman } \\
\text { Better outcomes } \\
\text { compared to IVM } \\
\text { of cryopreserved } \\
\text { immature oocytes }\end{array}$ & $\begin{array}{l}\text { Delays cancer treatment } \\
\text { by } 2-3 \text { weeks }\end{array}$ & $\begin{array}{l}\text { Presence of a Cl to } \\
\text { hormonal stimulation * }\end{array}$ \\
\hline $\begin{array}{l}\text { Immature oocyte } \\
\text { cryopreservation }\end{array}$ & $\begin{array}{l}\text { Experimental method } \\
\text { Women without partner or } \\
\text { who do not want to use } \\
\text { donated sperm }\end{array}$ & $\begin{array}{l}\text { Allows immediate } \\
\text { cancer treatment } \\
\text { Legal property } \\
\text { of the woman } \\
\text { Less damage is caused } \\
\text { by cryopreservation } \\
\text { of immature oocytes } \\
\text { than mature oocytes }\end{array}$ & $\begin{array}{l}\text { Data on efficacy in cancer } \\
\text { patients are not available }\end{array}$ & \\
\hline Ovarian tissue transplantation & Highly experimental & $\begin{array}{l}\text { Restoration of } \\
\text { endocrine function }\end{array}$ & $\begin{array}{l}\text { Invasive procedure } \\
\text { Risk of reintroduction of } \\
\text { aggressive cancer cells in } \\
\text { some type of cancer ** }\end{array}$ & Women older than 39 years \\
\hline In vitro follicle maturation (IVM) & $\begin{array}{l}\text { Highly experimental } \\
\text { Alternative to tissue } \\
\text { transplantation }\end{array}$ & $\begin{array}{l}\text { Minimal risk for ovarian } \\
\text { hyper stimulation } \\
\text { syndrome }\end{array}$ & Technical difficulties & \\
\hline $\begin{array}{l}\text { Oophoropexy or Ovarian } \\
\text { transposition }\end{array}$ & Experimental methods & $\begin{array}{l}\text { Can be used for } \\
\text { therapies requiring } \\
\text { pelvic irradiation } \\
\text { Ovarian protection } \\
\text { Possible spontaneous } \\
\text { pregnancy }\end{array}$ & $\begin{array}{l}\text { No protection against } \\
\text { chemotherapy or } \\
\text { whole-body irradiation } \\
\text { Carcinogenic risk }\end{array}$ & \\
\hline
\end{tabular}

${ }^{*}$ Contraindications $(\mathrm{Cl})$ to hormonal stimulation: prepubertal girls, hormone-responsive cancer, polycystic ovary syndrome

**Significantly elevated risk in patients with leukemia or ovarian tumor

Table 2 Outcomes of fertility preservation options in cancer patients in the world

\begin{tabular}{lllllll}
\hline FP option & Survey & Country & N & Mean age & Pregnancies & Live Births \\
\hline $\begin{array}{l}\text { Embryo freezing after } \\
\text { ovarian stimulation }\end{array}$ & Barcroft et al., 2013, [30] & UK & 42 & $31.9 \pm 3.9$ & 3 (1 twin) & 3 \\
$\begin{array}{l}\text { Slow freezing embryos } \\
\text { after ovarian stimulation }\end{array}$ & Lee et al., 2012, [31] & USA (NY) & 151 & $36.2 \pm 4.1$ (LD group) * & 15 (LD group) & 9 (LD group) \\
$\begin{array}{l}\text { Oocyte vitrification } \\
\begin{array}{l}\text { Ovarian tissue } \\
\text { tranplantation }\end{array}\end{array}$ & Garcia-Velasco et al., 2013 [32] & Spain & $47.9 \pm 4.5$ (HD group) & 11 (HD group) & 2 (LD group) \\
$\begin{array}{l}\text { Ovarian tissue } \\
\text { transplantation }\end{array}$ & Donnez et al., 2013, [33] & Belgium Denmark Spain & 60 & $31.9 \pm 5.1$ & 2 & 1 \\
\hline
\end{tabular}


founded in 2006, includes 100 centers in Germany, Austria and Switzerland to date. This network will now register their cases in the INCIP network. A German team [17] studied the impact of the creation of the FertiPROTEKT network and showed a significant increase in pregnancies within the first 2 years after breast cancer diagnosis in the period from 2010 to 2012 compared to the period from 2000 to 2002 .

In the available literature, the governance of oncofertility is clearly identified in the public health policies of 4 countries: USA, Canada, Brazil and Australia-New Zealand. Table 3 presents networks and strategies of coverage worldwide. The French Society of Oncofertility was created as an association in 2013. The aim was to inform health professionals and the general public about the oncofertility field and to establish best oncofertility practices. In the development process, this association, located in Bondy, should be able to extend its task force to reach national scope. The European Society of Human Reproduction and Embryology (ESHRE) established in early 2017 a Special Interest Group focusing on FP, with the mission to support collaboration between European countries and with relevant professional bodies and societies. Health networks specialized in cancer research sometimes have a fertility preservation axis. In Europe, the ESGO has a FP task force responsible for promoting knowledge among healthcare workers and patients about oncofertility through national and international collaboration among specialist healthcare workers to promote research in order to develop new strategies for FP. In France, the regional network ONCOPACA has developed a regional Cancer and Fertility platform and a regional charter. FP is an objective of the French national Cancer Plan for the period 2014-2019, although there is no structured national network as yet. The Japanese Society for Fertility Preservation and the Korean Society for Fertility Preservation founded respectively in 2012 in Japan and 2013 in Korea, have created national FP networks including the oncofertility field. In low and middle countries, no structured preservation network was identified. In a study conducted in 2015, Mahajan [18] expressed the need for India to structure a multidisciplinary collaborative network to improve awareness of healthcare workers and FP service availability.

National guidelines have been established in the U.S.A. by the American Society of Clinical Oncology (ASCO) [19] and the American Society for Reproductive Medicine (ASRM) [20] in 2013 and by the National Comprehensive Cancer Network (NCCN) in 2014 [21]. In Europe, guidelines have also been published by the ESHRE [22] and by the European Society of Medical Oncology (ESMO) 2013 [23]. There was also the publication of a report in France by the National Cancer Institute (INCa) and the Biomedicine Agency in 2013 [6] and in the U.K. by National Institute for Health and Clinical Excellence (NICE) in 2004. In AustraliaNew Zealand, an Australasian Oncofertility Consortium

Table 3 Networks and strategies of coverage worldwide

\begin{tabular}{|c|c|c|c|c|}
\hline Location & National Health networks & Role and Actions of the network & Tools & Other cooperating networks \\
\hline \multirow[t]{2}{*}{ USA } & $\begin{array}{l}\text { National Physicians } \\
\text { Cooperative (NPC) }\end{array}$ & $\begin{array}{l}59 \text { clinical sites across the US } \\
\text { Information for patients, } \\
\text { personalized management plan for patients } \\
\text { Global fertility hotline } \\
\text { Biological research } \\
\text { Provides optimized protocols } \\
\text { (including non biological parenting options) }\end{array}$ & & $\begin{array}{l}\text { - American society for } \\
\text { reproductive Medicine (ASRM) } \\
\text { - American Society of Clinical } \\
\text { Oncology (ASCO) }\end{array}$ \\
\hline & $\begin{array}{l}\text { American Oncofertility } \\
\text { Consortium }\end{array}$ & $\begin{array}{l}\text { Produce guidelines } \\
\text { Share informed consent document } \\
\text { and consensus group decisions } \\
\text { Implement standardized protocols } \\
\text { Research into the societal, ethical and legal } \\
\text { implications providing new perspectives on } \\
\text { patient decision making }\end{array}$ & $\begin{array}{l}\text { iSave Fertility app } \\
\text { for physicians in } \\
\text { English and Spanish } \\
\text { Myoncofertility } \\
\text { website for patients, } \\
\text { parents and partners }\end{array}$ & \\
\hline Canada & Oncofertility Referral Network & $\begin{array}{l}\text { Platform that links patients, } \\
\text { physicians and fertility clinics } \\
\text { Resources for professionals } \\
\text { Resources for patients }\end{array}$ & & $\begin{array}{l}\text { - The government agency } \\
\text { Assisted Human } \\
\text { Reproduction Canada } \\
\text { - Canadian Cancer Society } \\
\text { - Cancer Knowledge Network } \\
\text { (Journal current oncology) }\end{array}$ \\
\hline Brazil & $\begin{array}{l}\text { Rede Brasileira de Oncofertilidade/ } \\
\text { Brasilian Oncofertility Consortium }\end{array}$ & $\begin{array}{l}8 \text { centers throughout Brazil } \\
\text { Establish research projects and } \\
\text { exchange on fertility options }\end{array}$ & & \\
\hline Australia/ New Zealand & Australasian Oncofertility Registry & $\begin{array}{l}\text { Collect complete oncofertility data } \\
\text { set from cancer and fertility centers } \\
\text { Research projects }\end{array}$ & & $\begin{array}{l}\text { - Australasian Oncofertility } \\
\text { Consumer group }\end{array}$ \\
\hline
\end{tabular}


Charter was produced in 2015 by the Australasian Oncofertility Consortium. The International Society for Fertility Preservation established recommendations about this topic in June 2012 [24]. All these guidelines recommend universal access to FP facilities for young patients with cancer.

Table 4 presents an evaluation of knowledge, attitudes and practices of healthcare providers in the world. Forman et al. [25] concluded in a nationwide survey in the USA that $86 \%$ of oncologists consider it acceptable to sacrifice less than 5\% reduction in disease-free survival to preserve fertility outcomes and $36 \%$ suggested that women would be willing to sacrifice more than 5\%. Lack of time and lack of knowledge are identified as the main barriers to the initiation of FP discussion. Training of healthcare providers remains a challenge to meet the needs of quality of life of the patients. Kohlër et al. [26] showed that gender disparities in access to healthcare are strikingly against women. Table 5 presents an evaluation of healthcare circuits for patients worldwide.

\section{International challenge of fertility preservation strategies}

The paucity of nationwide referral networks is a challenge for the activities of international networks. Access to services remains limited, even in developed countries with specific health networks $[13,27]$ and to the best of our knowledge, no action plan has been published to develop the field of oncofertility in low and middleincome countries.

Table 4 Evaluation of existing models- Knowledge, attitudes and practices of healthcare providers in the world

\begin{tabular}{|c|c|c|c|}
\hline Location, Year & Authors, Reference & Study design & Main results \\
\hline USA, 2011 & Köhler et al., [26] & 209 pediatric oncologists & $\begin{array}{l}83 \% \text { of pediatric oncologists acknowledged that fertility } \\
\text { threats to female patients are a major concern for them } \\
\text { Only } 12 \% \text { reported that they refer at least } 50 \% \text { of female } \\
\text { cancer patients to a fertility specialist prior to } \\
\text { cancer treatment } \\
<50 \% \text { were aware of the ASCO recommendations } \\
\text { published in } 2006\end{array}$ \\
\hline
\end{tabular}

USA, $2010 \quad$ Forman et al., [25] 249 oncologists

Canada, 2012 Yee et al. [35]

Canada, 2013 Ronn and Holzer, [13]

All FP services available

Iran, 2011

Ghorbani et al., [36]

France, 2013 Préaubert et al., [37]

UK, 2008 Cannell [38]

UK, 2013

Adams, Hill and Watson, [39]

India, 2016 Mahajan et al. [9] 85\% oncologists:
100 oncologists

30 specialists: $15 \%$ other specialists in cancer treatment

225 French doctors from the PACA region

84 Primary Care Trusts

157 gynecologists
95\% routinely discussed a treatment's impact on fertility: $93 \%$ for gynecologic oncologists vs $60 \%$ for other oncologists Although $82 \%$ have referred patients to reproductive endocrinologists, more than half rarely refer.

$45 \%$ did not know where to refer patients for female fertility preservation

$63 \%$ of the responding non-IVF fertility centres do not provide any FP services, including consultations. $80 \%$ of the responding IVF fertility centres provided both consultations and FP services for women with cancer, with an additional $10 \%$ saying that they provide consultations only.

$67 \%$ were attentive to the damaging effects of radiochemotherapy on fertility at the time of diagnosis $40 \%$ insisted that the FP topic should be brought up by patients themselves.

Only $46 \%$ of the oncologists knew about FP techniques The greatest barrier to parental acceptance of FP for children was lack of information (41\%)

58\% felt a lack information about indications and FP techniques

$54 \%$ referred no patients to FP consultation over a period of 6 months

$46 \%$ did not provide patient information $33 \%$ did not commission facilities for embryo storage and $37 \%$ did not commission facilities for oocyte storage

87\% expressed a need for information

Only $38 \%$ reported routinely providing patients with written information

$23 \%$ had never consulted any FP guidelines

$1 / 3$ did not usually refer patients to a specialist fertility service.

$81 \%$ agreed with the ASCO recommendations $42 \%$ routinely discussed cancer impact on fertility $37 \%$ routinely discussed a treatment's impact on fertility 
Table 5 Evaluation of healthcare circuits for patients worldwide

\begin{tabular}{|c|c|c|c|}
\hline Location & Authors, Date, Reference & Study design & Results \\
\hline USA & Zebrack et al., 2004, [40] & 32 childhood cancer survivors & $\begin{array}{l}\text { Only } 1 / 3 \text { of patients had a discussion with the medical team on } \\
\text { the risk of pregnancy during or after treatment. }\end{array}$ \\
\hline USA & Salih et al., 2015, [41] & $\begin{array}{l}222 \text { female childhood cancers } \\
\text { survivors [ } \leq 21 \text { years] }\end{array}$ & $\begin{array}{l}31 \% \text { patients older than } 13 \text { years had decreased ovarian reserve } \\
\text { or have premature ovarian failure } \\
33 \text { patients had reproductive counseling prior to treatment, } \\
\text { only } 2 \text { had counseling during or after treatment } \\
1 \text { patient had oocryopreservation prior to initiation of chemotherapy. }\end{array}$ \\
\hline USA & Kim et al., 2012, [42] & 183 breast cancer patients & $\begin{array}{l}42 \% \text { did not undergo FP treatment } \\
\text { Women who had FP treatment were older, wealthier and had } \\
\text { lower cancer stage }\end{array}$ \\
\hline USA & Letourneau et al., 2012, [43] & 1041 women with cancer & $\begin{array}{l}61 \% \text { were counseled on the risk of cancer treatment for fertility } \\
4 \% \text { of women pursued FP } \\
\text { Disparities in access to FP were observed based on educational level, } \\
\text { ethnicity and sexual orientation }\end{array}$ \\
\hline France & Huyghe et al., 2009, [44] & 1000 cancer patients & $\begin{array}{l}20 \text { to } 30 \% \text { would like to have more information on the potential } \\
\text { risk of premature ovarian failure. } \\
1 / 3 \text { aged less than } 50 \text { years would have liked a fertility } \\
\text { consultation before cancer treatment. } \\
21 \% \text { of women would definitely want to visit a reproductive } \\
\text { health clinic in the next year. }\end{array}$ \\
\hline France & Bouhnik et al., 2014, [45] & $\begin{array}{l}4349 \text { cancer survivors } 2 \text { years } \\
\text { after diagnosis }\end{array}$ & $\begin{array}{l}31.9 \% \text { of women under } 45 \text { had a parental project } \\
2 / 3 \text { under } 45 \text { did not have FP discussion prior to initiation of } \\
\text { treatment } \\
2.2 \% \text { of women under } 45 \text { had access to cryopresenvation of gametes }\end{array}$ \\
\hline Germany & Geue et al., 2013, [29] & 149 cancer patients [18-45 years] & $\begin{array}{l}74 \% \text { of patients wanted to have children at the time of diagnosis } \\
50 \% \text { of those who wanted a child needed supportive care } \\
\text { concerning this issue } \\
60 \% \text { of the total sample had discussed fertility aspects with their } \\
\text { oncologists and } 20 \% \text { with fertility specialists } \\
\text { Men (56\%) underwent fertility preservation more often } \\
\text { than women (31\%) }\end{array}$ \\
\hline Sweden & Armuand et al., 2012, [46] & 484 Patients(men and women) & $\begin{array}{l}48 \% \text { of women reported that they received information } \\
\text { about treatment impact on fertility. } \\
14 \% \text { reported that they received information about FP. } \\
\text { Only } 2 \% \text { underwent FP } \\
\text { Large gender disparities in access to FP care }\end{array}$ \\
\hline UK & Corney and Swinglehurst, 2014, [47] & $\begin{array}{l}19 \text { childless women aged } \\
\text { below } 45 \text { withbreast cancer }\end{array}$ & $\begin{array}{l}\text { Only half were given the opportunity to pursue assisted } \\
\text { reproductive techniques prior to chemotherapy. }\end{array}$ \\
\hline
\end{tabular}

Financial costs for FP treatments are one of the major challenges thus far. In the U.S.A., in the state of Massachusetts, initial oocyte retrieval without medication costs 6000-12,000 USD and annual storage is around 440 USD [28]. In Canada, oocyte retrieval with intracytoplasmic sperm injection without medication is reported to cost 6000-8150 CAD, embryo cryopreservation ranged from 500 to $1200 \mathrm{CAD}$ and oocyte retrieval and cryopreserved ranged from 2900 to 5400 CAD. The annual maintenance fee for cryopreservation and storage range from 200 to 800 CAD [13]. In 2013, Quebec was the only province in Canada that covered this cost burden. In Germany, cryopreservation of fertile eggs costs about \$3400 and annual storage about $\$ 280$ every year. In India, Mahajan et al. [9] showed in a study of Indian gynecologists that the second most common reason for not discussing the impact of cancer treatment on fertility was the cost of FP techniques (reason expressed by $34.5 \%$ of the gynecologists), after lack of available FP services in the city (35.9\%). Geue et al. [29] indicated that these annual storage fees could easily become a psychological pressure for couples. In Belgium, the costs for $\mathrm{GnRH}$ analogues in not reimbursed. France is one of the few countries that offer women the assurance of financial reimbursement. Globally, financial reimbursement remains a thorny issue and FP imposes significant costs worldwide, restricting care access to women with low financial resources.

\section{Conclusion}

By providing the international context of the organization of the oncofertility sector, this literature review aims to contribute to the development of new structures for the coordination of fertility preservation care in female cancer patients, particularly in low and middle-income countries. 
There is a structural gap in health care policies. Overall, the lack of information is demonstrated by the different internationally published surveys. Health care delivery should be organized in order to meet this need. The mobilization of skills acquired by collaboration through existing networks will make it possible to better structure this sector. To date, management strategies for oncofertility in the world are still fragile and unequal. To structure the oncofertility sector, a multidisciplinary project enabling teams to work together should be implemented, particularly in low and middleincome countries.

\begin{abstract}
Abbreviations
ASCO: American Society of Clinical Oncology; ASRM: American Society for Reproductive Medicine; ESGO: European Society of Gynaecological Oncology; ESHRE: European Society of Human Reproduction and Embryology; ESMO: European Society of Medical Oncology; FP: Fertility preservation; INCa: National Cancer Institute; INCIP: International Network on cancer, Infertility and Pregnancy; IVF: In vitro Fertilization; IVM: InVitro Maturation; NCCN: National Comprehensive Cancer Network
\end{abstract}

\section{Acknowledgements}

The authors gratefully acknowledge the assistance of the Martinique cancer Registry team and the funding assistance of Territorial Collectivity of Martinique. We thank Fiona Ecarnot, MSc (EA3920, University Hospital Besancon, France) for editorial assistance.

\section{Funding}

The authors gratefully acknowledge the funding assistance of Territorial Collectivity of Martinique. This funding constitutes a PhD scholarship. The funding body had no role in the design of the study and collection, analysis, and interpretation of data and in writing the manuscript.

\section{Availability of data and materials}

Not applicable

\section{Authors' contributions}

KM was a major contributor in writing the manuscript, made substantial contributions to conception and design, or acquisition of data, or analysis and interpretation of data; and agreed to be accountable for all aspects of the work in ensuring that questions related to the accuracy or integrity of any part of the work are appropriately investigated and resolved. FA revising it critically for important intellectual content. JVB revising it critically for important intellectual content. CJ made substantial contributions to conception and design; been involved in drafting the manuscript and revising it critically for important intellectual content. EJ been involved in drafting the manuscript and revising it critically for important intellectual content. All authors read and approved the final manuscript.

\section{Ethics approval and consent to participate}

Not applicable

\section{Consent for publication}

Not applicable

\section{Competing interests}

The authors declare that they have no competing interests.

\section{Publisher's Note}

Springer Nature remains neutral with regard to jurisdictional claims in published maps and institutional affiliations.

\section{Author details}

'Laboratory CELTEC Cancer and Environment EA4546, University of the French West-Indies, Pointe-à-Pitre, Guadeloupe. ${ }^{2}$ Department of Obstetrics \& Gynaecology, UZ Gasthuisberg / Katholieke Universiteit Leuven Herestraat 49, 3000 Leuven, Belgium. ${ }^{3}$ Oncology Haematology Urology Pathology
Department, UF 1441 Cancer Research and Registry, University Hospital of Martinique, 127 Route de Redoute, Les jardins de la Mouïna, 97200 Fort-de-France, Martinique. ${ }^{4}$ Gynaecology, Obstetrics Department, University Hospital of Guadeloupe, Pointe-à-Pitre, Guadeloupe.

Received: 22 February 2017 Accepted: 24 January 2018

Published online: 17 February 2018

\section{References}

1. ONLINE ANALYSIS > PREDICTION [Internet]. [adressed 5 sept 2017]. Available on: http://globocan.iarc.fr/Pages/burden_sel.aspx

2. Kim S-Y, Kim SK, Lee JR, Woodruff TK. Toward precision medicine for preserving fertility in cancer patients: existing and emerging fertility preservation options for women. J Gynecol Oncol. mars 2016;27(2):e22.

3. Merlet $F$, Hoog-Labouret N. Integrate fertility preservation in cancer management (in part II: a personalized and integrated treatment programme to better meet the needs of patients). Oncologie. 1 sept 2014; 16(1):35-38.

4. Lee SJ, Schover LR, Partridge AH, Patrizio P, Wallace WH, Hagerty K, et al. American Society of Clinical Oncology recommendations on fertility preservation in cancer patients. J Clin Oncol Off J Am Soc Clin Oncol. 20 juin 2006:24(18):2917-2931.

5. Woodruff TK. The Oncofertility consortium-addressing fertility in young people with cancer. Nat Rev Clin Oncol. août 2010;7(8):466-475.

6. Bernier-Chastagner V, Bujan L, Martelli H, Poirot C, Rives N. Conséquences des traitements des cancers et préservation de la fertilité - Etat des connaissances et propositions. Institut National Du Cancer, Agence de biomédecine; 2013 Février

7. Dillon KE, Gracia CR. Pediatric and young adult patients and oncofertility. Curr Treat Options in Oncol. juin 2012;13(2):161-173.

8. Schover $L R$, van der Kaaij $M$, van Dorst E, Creutzberg C, Huyghe E, Kiserud CE. Sexual dysfunction and infertility as late effects of cancer treatment. EJC Suppl EJC Off J EORTC Eur Organ Res Treat Cancer Al. juin 2014;12(1):41-53.

9. Mahajan N, Patil M, Kaur S, Kaur S, Naidu P. The role of Indian gynecologists in oncofertility care and counselling. J Hum Reprod Sci. sept 2016;9(3):179-186.

10. Rajendranath R, Veeraiah S, Ramesh A, Sagar TG. Late effects of treatment in survivors of childhood cancer from a tertiary cancer center in South India. South Asian J Cancer. 2014;3(1):60-5.

11. Ben Charif A, Bouhnik A-D, Courbière B, Rey D, Préau M, Bendiane M-K, et al. Sexual health problems in French cancer survivors 2 years after diagnosisthe national VICAN survey. J Cancer Surviv Res Pract. 2016;10(3):600-9.

12. Resetkova N, Hayashi M, Kolp LA, Christianson MS. Fertility preservation for Prepubertal girls: update and current challenges. Curr Obstet Gynecol Rep. 1 déc 2013;2(4):218-225.

13. Ronn R, Holzer HEG. Oncofertility in Canada: an overview of Canadian practice and suggested action plan. Curr Oncol Tor Ont. oct 2013;20(5):e465-e474.

14. Cohn F. Oncofertility and informed consent: addressing beliefs, values, and future decision making. Cancer Treat Res. 2010;156:249-58.

15. Dittrich R, Hackl J, Lotz L, Hoffmann I, Beckmann MW. Pregnancies and live births after 20 transplantations of cryopreserved ovarian tissue in a single center. Fertil Steril. 1 févr 2015;103(2):462-468.

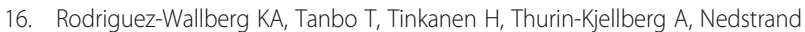
E, Kitlinski ML, et al. Ovarian tissue cryopreservation and transplantation among alternatives for fertility preservation in the Nordic countries compilation of 20 years of multicenter experience. Acta Obstet Gynecol Scand. 1 sept 2016;95(9):1015-1026

17. Kalousidou N, Kyvernitakis I, Waehlert L, Engelhard J, Kostev K, Ziller V. [Pregnancy after breast cancer in germany - results of a retrospective database analysis]. Z Geburtshilfe Neonatol. août 2015;219(4):176-180.

18. Mahajan N. Fertility preservation in female cancer patients: an overview. J Hum Reprod Sci. 2015:8(1):3-13.

19. Loren AW, Mangu PB, Beck LN, Brennan L, Magdalinski AJ, Partridge AH, et al. Fertility preservation for patients with cancer: American Society of Clinical Oncology clinical practice guideline update. J Clin Oncol Off J Am Soc Clin Oncol. 1 juill 2013;31(19):2500-2510.

20. Ethics Committee of American Society for Reproductive Medicine. Fertility preservation and reproduction in patients facing gonadotoxic therapies: a committee opinion. Fertil Steril. nov 2013;100(5):1224-1231.

21. Coccia PF, Pappo AS, Altman J, Bhatia S, Borinstein SC, Flynn J, et al. Adolescent and young adult oncology, version 2.2014. J Natl Compr Cancer Netw JNCCN. janv 2014;12(1):21-32; quiz 32. 
22. Clinical management planning for fertility preservation in female cancer patient. Stochholm: European Society of Human Reproduction and Embryology (ESHRE); 2011 juill.

23. Peccatori FA, Azim HA, Orecchia R, Hoekstra HJ, Pavlidis N, Kesic V, et al. Cancer, pregnancy and fertility: ESMO clinical practice guidelines for diagnosis, treatment and follow-up. Ann Oncol Off J Eur Soc Med Oncol. oct 2013;24 Suppl 6:vi160-vi170

24. Kim SS, Donnez J, Barri P, Pellicer A, Patrizio P, Rosenwaks Z, et al. Recommendations for fertility preservation in patients with lymphoma, leukemia, and breast cancer. J Assist Reprod Genet. juin 2012;29(6):465-468.

25. Forman EJ, Anders CK, Behera MA. A nationwide survey of oncologists regarding treatment-related infertility and fertility preservation in female cancer patients. Fertil Steril. oct 2010;94(5):1652-1656.

26. Köhler TS, Kondapalli LA, Shah A, Chan S, Woodruff TK, Brannigan RE. Results from the survey for preservation of adolescent reproduction (SPARE) study: gender disparity in delivery of fertility preservation message to adolescents with cancer. J Assist Reprod Genet. mars 2011;28(3):269-277.

27. Curado MP. Cancer incidence in African continent. Hands on to produce more information. J Afr Cancer Afr J Cancer. févr 2014:6(1):1-2.

28. Harwood K. Egg freezing: a breakthrough for reproductive autonomy? Bioethics. janv 2009;23(1):39-46

29. Geue K, Richter D, Schmidt R, Sender A, Siedentopf F, Brähler E, et al. The desire for children and fertility issues among young German cancer survivors. J Adolesc Health Off Publ Soc Adolesc Med. mai 2014;54(5):527-535.

30. Barcroft J, Dayoub N, Thong KJ. Fifteen year follow-up of embryos cryopreserved in cancer patients for fertility preservation. J Assist Reprod Genet. nov 2013;30(11):1407-1413.

31. Lee S, Oktay K. Does higher starting dose of FSH stimulation with letrozole improve fertility preservation outcomes in women with breast cancer? Fertil Steril. oct 2012;98(4):961-4.e1.

32. Garcia-Velasco JA, Domingo J, Cobo A, Martínez M, Carmona L, Pellicer A. Five years' experience using oocyte vitrification to preserve fertility for medical and nonmedical indications. Fertil Steril juin. 2013;99(7):1994-9.

33. Donnez J, Dolmans M-M, Pellicer A, Diaz-Garcia C, Sanchez Serrano M, Schmidt KT, et al. Restoration of ovarian activity and pregnancy after transplantation of cryopreserved ovarian tissue: a review of 60 cases of reimplantation. Fertil Steril. mai 2013;99(6):1503-1513.

34. Dolmans M-M, Jadoul P, Gilliaux S, Amorim CA, Luyckx V, Squifflet J, et al. A review of 15 years of ovarian tissue bank activities. J Assist Reprod Genet mars. 2013:30(3):305-14.

35. Yee S, Buckett W, Campbell S, Yanofsky R, Barr RD. A national study of the provision of oncofertility services to female patients in Canada. J Obstet Gynaecol Can JOGC J Obstet Gynecol Can JOGC. sept 2012;34(9):849-858.

36. Ghorbani B, Madahi P, Shirazi E, Ardekani HS, Kamali K. Iranian oncologists' attitude towards fertility preservation in a sample group. J Reprod Infertil. janv 2011;12(1):33-36.

37. Préaubert L, Poggi P, Pibarot M, Delotte J, Thibault E, Saias-Magnan J, et al. [Fertility preservation among patients with cancer: report of a French regional practical experience]. J Gynecol Obstet Biol Reprod (Paris). mai 2013;42(3):246-251

38. Cannell E. Postcode lottery for fertility-preservation facilities. Lancet Oncol. 1 mars 2008;9(3):206

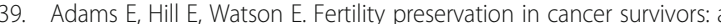
national survey of oncologists' current knowledge, practice and attitudes. $\mathrm{Br}$ J Cancer. 30 avr 2013;108(8):1602-1615.

40. Zebrack BJ, Casillas J, Nohr L, Adams H, Zeltzer LK. Fertility issues for young adult survivors of childhood cancer. Psychooncology. oct 2004;13(10):689-699.

41. Salih SM, Elsarrag SZ, Prange E, Contreras K, Osman RG, Eikoff JC, et al. Evidence to incorporate inclusive reproductive health measures in guidelines for childhood and adolescent cancer survivors. J Pediatr Adolesc Gynecol. avr 2015;28(2):95-101.

42. Kim J, Oktay K, Gracia C, Lee S, Morse C, Mersereau JE. Which patients pursue fertility preservation treatments? A multi-center analysis of the predictors of fertility preservation in women with breast cancer. Fertil Steril. mars 2012;97(3):671-676

43. Letourneau JM, Smith JF, Ebbel EE, Craig A, Katz PP, Cedars Ml, et al. Racial, socioeconomic, and demographic disparities in access to fertility preservation in young women diagnosed with cancer. Cancer. 15 sept 2012;118(18):4579-4588.

44. Huyghe E, Sui D, Odensky E, Schover LR. Needs assessment survey to justify establishing a reproductive health clinic at a comprehensive cancer center. J Sex Med janv. 2009;6(1):149-63.
45. Bouhnik A-D, Bendiane M-K, Cortaredona S, Sagaon Teyssier L, Rey D, Berenger

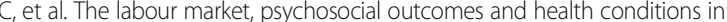
cancer survivors: protocol for a nationwide longitudinal survey 2 and 5 years after cancer diagnosis (the VICAN survey). BMJ Open. 24 mars 2015;5(3).

46. Armuand GM, Rodriguez-Wallberg KA, Wettergren L, Ahlgren J, Enblad G, Höglund $M$, et al. Sex differences in fertility-related information received by young adult cancer survivors. J Clin Oncol Off J Am Soc Clin Oncol. 10 juin 2012;30(17):2147-2153.

47. Corney RH, Swinglehurst AJ. Young childless women with breast cancer in the UK: a qualitative study of their fertility-related experiences, options, and the information given by health professionals. Psychooncology. janv 2014;23(1):20-26.

\section{Submit your next manuscript to BioMed Central and we will help you at every step:}

- We accept pre-submission inquiries

- Our selector tool helps you to find the most relevant journal

- We provide round the clock customer support

- Convenient online submission

- Thorough peer review

- Inclusion in PubMed and all major indexing services

- Maximum visibility for your research

Submit your manuscript at www.biomedcentral.com/submit
) Biomed Central 